ALASKAN GEOLOGY BRANCH

TECHNICAL BATA FILE

UNITED STATES DEPARTMENT OF THE INTERIOR

GEOLOGICAL SURVEY

\title{
Preliminary Field Geotechnical and Geophysical Logs from a Drill Hole in the Capps Coal Field, Cook Inlet Region, Alaska
}

\section{By}

Alan F. Chleborad, Lynn A. Yehle, Henry R. Schmoll, and Cynthia A. Gardner

Open-File Report 80-393 


\section{Illustrations}

Figure 1. Index map showing the location of the drill site......... 2

2. Generalized 1ithologic log for the vicinity of the drill site................................... 4

3. Map showing the location of drill site in relation to proposed mining areas (information from Placer Amex, Inc., status report of December 1977) and nearby landslide

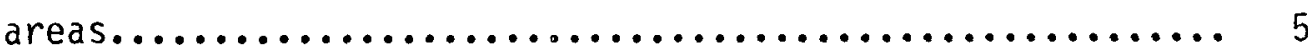

4. Relationship between hardness and unconfined compressive strength.

\section{In pocket}

5. Preliminary geotechnical log

6. Caliper $\log$

7. Natural-gamma log

8. Gamma-gamma $\log$

9. Neutron $\log$

10. Temperature $\log$ 
Introduction........................................ 1

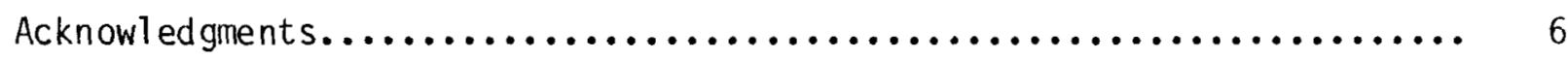

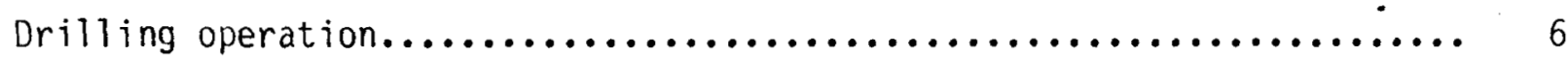

Field geotechnical logging operation...................... 8

Summary of geotechnical properties....................... 10

Description of geologic materials..................... 10

Discontinuities.................................... 11

Strength properties.............................. 11

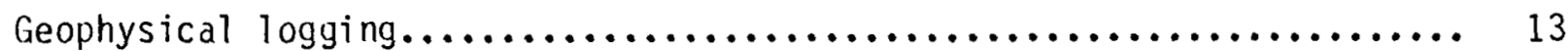

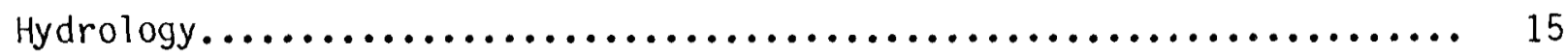

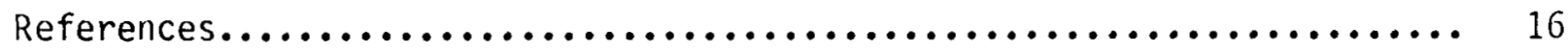


Preliminary Field Geotechnical and Geophysical Logs from

a Drill Hole in the Capps Coal Field, Cook Inlet

Region, Alaska

By Alan F. Chleborad, Lynn A. Yehle, Henry R. Schmoll, and Cynthia A. Gardner

\section{Introduction}

The drilling and logging activity described in this report was undertaken in August 1979, as part of the Energy Lands program of the U.S. Geological Survey. The general objectives of the project, of which this work is a part, are to provide an understanding of the nature, location, and extent of the engineering and environmental concerns in potential coal-development areas of the Cook Inlet region, Alaska. The geotechnical and geophysical logs presented in this report provide some of the basic physical-property and engineering data needed to evaluate geologic hazards, and to predict the response of geologic materials to large-scale coal mining and related development in the Capps coal field of the Beluga coal area. Specifically, the information may be used to help determine such things as natural- and cutslope stability, spoil-pile stability, ground response to seismic activity, blasting effects, excavatability, bulking characteristics, ground-water conditions, and erosion potential.

The drill site (fig. 1) is located on an upland approximately $100 \mathrm{~km}$ west of Anchorage, Alaska, and $38 \mathrm{~km}$ from Cook Inlet. The drilling and core sampling involved strata of the lower 0ligocene to middle Miocene (Wolfe and Tanai, 1980) Tyonek Formation and overlying Quaternary glacial deposits. The geology and coal resources of the Beluga coal area were described by Barnes (1966). Subsequent7y, the Beluga Coal Company correlated coal beds (Capps and Waterfall beds) and described overburden material in the Capps coal field by 


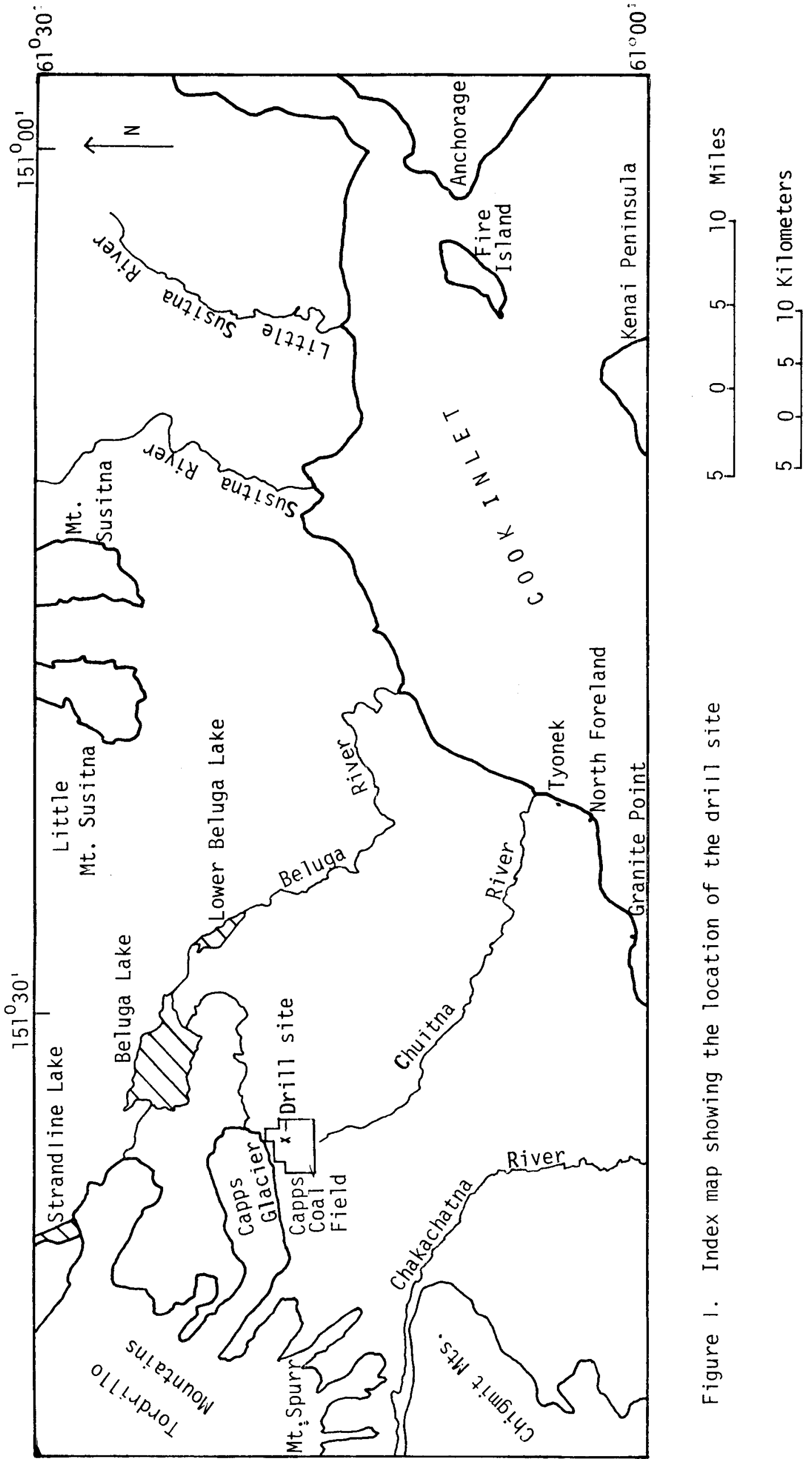


detailed drilling on a one-quarter mile grid basis (Patsch, 1975). A generalized log showing lithologies in the vicinity of the drill site is presented in figure 2. The $\log$ is based primarily on the drill-hole field log supplemented by outcrop information obtained during the 1978 and 1979 field seasons.

of the several coal fields in the Cook Inlet region, the Capps coal field appears to be one of the most likely to undergo large-scale development in the foreseeable future. A proposed open-pit mining plan (information from Placer Amex, Inc., status report of December 1977) calls for the sequential mining and reclamation of five areas in the Capps coal field (fig. 3 ). The drill site, also shown in figure 3 , is located in the third proposed mine area where, according to the mining plan, two major coal beds (the Capps and Waterfall beds) and approximately $90 \mathrm{~m}$ of spoil material (mined overburden and interburden) would be involved in the mining operation.

Several large landslides near the drill site (fig. 3 ) involve coalbearing strata stratigraphically equivalent to the material sampled at the drill site. Data provided in the present report and data from laboratory testing of core samples (when available) should be particularly useful in identifying factors involved in the mass movement process and in analyzing natural- and cut-slope stability. 


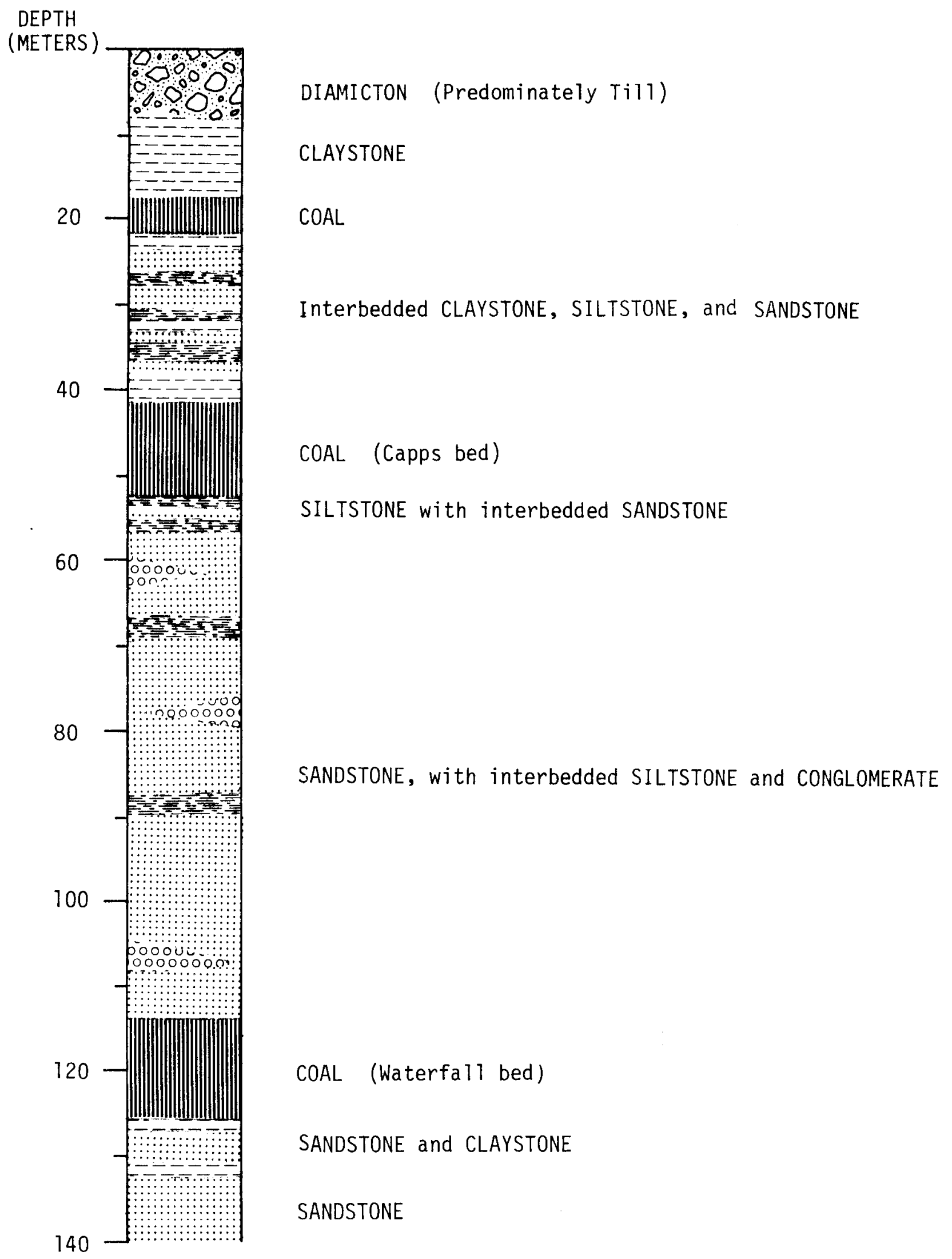

Figure 2. Generalized lithologic log for the vicinity of the drill site 


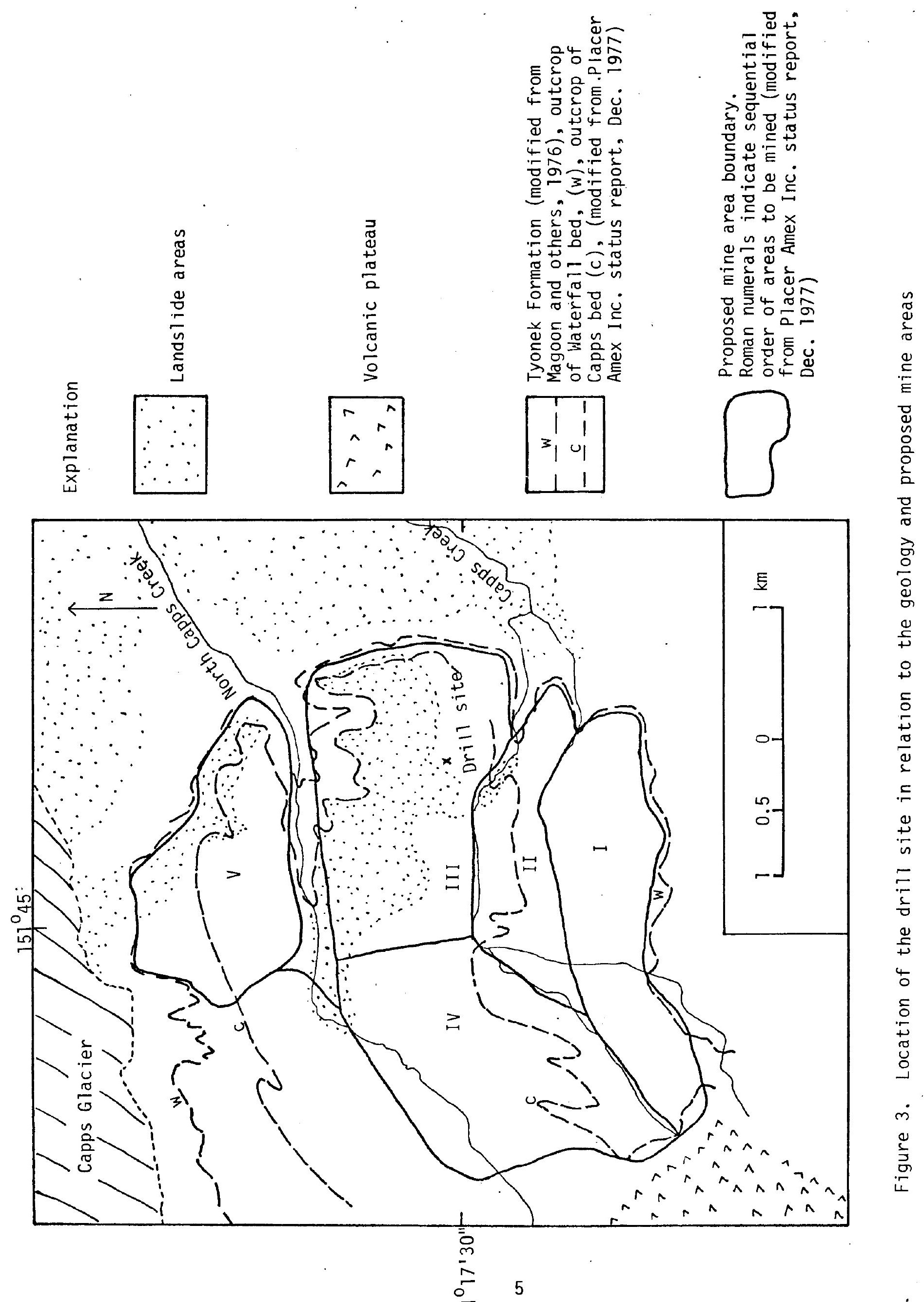




\section{Acknowledgrnents}

The authors are grateful for the support and technical assistance of colleagues L. L. Dearborn, A. J. Feulner, G. L. Nelson, B. Carpenter, C. B. Boydsten, H. D. Gomez, T. L. Hermann, R. W. Nichols, H. W. Olsen, A. D. Pasch, and P. S. Powers.

The Beluga Coal Company, a wholly owned subsidiary of Placer Amex, Inc., generously contributed information useful in planning the drilling operation.

We thank Cook Inlet Region, Inc., owners of the land, for permitting access.

\section{Drilling operation}

The remoteness and inaccessibility of the drilling location necessitated the use of tracked vehicles and fixed-wing aircraft to transport equipment, personnel, and supplies. The drilling contractor used a Failing Model $1500^{1}$ drill unit mounted on a tracked vehicle which, with several tracked camp trailers, were driven or pulled approximately $40 \mathrm{~km}$ across difficult terrain from near cook Inlet to the drill site. After lengthy delays related to adverse weather and ground conditions the drill rig arrived at the site on August 23, 1979, and drilling commenced the following day. A rotary HQ wireline core systern $(6.4-\mathrm{cm}$ diameter core size) was used with the objective of obtaining continuous core suitable for physical property and strength testing. Due to alinernent and caving problems related to insufficient surface casing the first attempted drill hole was abandoned after reaching a depth of

\footnotetext{
$1^{1}$ The use of trade names is for descriptive purposes only and does not necessarily constitute endorsernent by the U.S. Geological Survey.
} 
$20 \mathrm{~m}$. Two additional attempts within $3 \mathrm{~m}$ of the first drill hole were also thwarted by difficult drilling in boulder-laden glacial deposits. These holes were also abandoned after reaching depths of less than $6 \mathrm{~m}$. In a fourth attempt (hole no. 1C-79), using a 12.8-cm diameter rock bit, surface casing was successfully set to a depth of approximately $9 \mathrm{~m}$. Core drilling was then continued, variously using carbide, regular diamond, and face-discharge diamond core bits in an effort to obtain good core sample. Drilling problems included nearly continuous circulation loss, excessive bit wear, and delays in getting replacement parts. Shearing of the core sample, attributed to abnormal rotation of the inner core barrel, was noted in core from the first abandoned hole. Quik-gel bentonite and Revert drill-mud additives were used in an effort to stabilize the hole, mitigate bit wear, and to stop the loss of circulation. A double tube core barrel with a split tube sampler $1.5 \mathrm{~m}$ long was used to collect core sample. Rates of drilling averaged about $1 \mathrm{~m} / \mathrm{h}$ but varied greatly depending largely on type and condition of the bit and the type of material being drilled. The alinement and condition of the near-vertical drill hole were maintained within tolerances necessary for geophysical logging and for the installation of a $5.1-\mathrm{cm}$ (outside diameter) plastic pipe. The plastic pipe was installed for proposed geothemal measurements. Drilling of the 121-m deep hole was accomplished on a continuous basis in two 12-hour shifts.

In addition to test hole no. 1C-79 described above, a 76-m deep test hole was drilled using an air-rotary method for the purpose of determining the hydrologic properties of the materials. The test hole, which is located approximately $30 \mathrm{~m}$ to the south and within a meter of the sane ground elevation as hole no. 1C-79, was cased with 15.2-cm I.D. (inside diameter) steel pipe and was intended to be used as a water-level observation well. 
However, the amount of water that entered the hole upon temination of drilling was not significant and the well will not be monitored on a regular basis (G. L. Nelson, U.S. Geological Survey, written conmun., 1979).

Field geotechnical logging operation

The retrieval, logging, testing, and packaging of the core was conducted in three basic steps.

First, the core sample in the split-tube sampler was transferred at the drill rig to a member of the logging team. Drilling information concerning time of recovery, depth of the cored interval, nature of the drilling fluid used, and hydrologic conditions, was obtained from the driller and recorded, then half of the split-tube sampler was removed to expose the core which, if necessary, was washed using a fine spray of water from an ordinary pressurized garden or weed sprayer. The core in the sampler was then photographed with a color instantaneous-development camera and with a 35-mm single-lens reflex camera. A card showing the tube number, the depth in meters and feet, and an appropriate page from a rock color chart (Goddard and others, 1948) was included in the photograph.

Second, the core was transferred to a logging table where it was carefully removed from the sample tube and examined by the logger. A graphic and abbreviated field-logging scheme (Rankilor, 1974) was used to log the core. Information regarding discontinuities, material type and color, laminations, hardness, and degree of weathering were recorded. As part of this step of the logging operation, strength index tests were performed on selected samples to detemine the range of rock hardness and to provide a base of strength data from the field to compare with subsequent laboratory tests. A pocket penetrometer strength tester (Soiltest, Inc., 1978) was used to test samples with an unconfined compressive strength of $0.5 \mathrm{MPa}$ (72.5 psi) or 
lower. The pocket penetrometer values have a direct correlation with uniaxial compressive strength. For material of greater strength (that is, >0.5 MPa) the point-load test (Broch and Franklin, 1972) was used. The point-load index value $\left(I_{s}\right)$ is an approximation of the uniaxial compressive strength using the correlative equation; compressive strength $=I_{S} \times 24$ (Franklin and others, 1972). The point-load values obtained are from single diametral tests. A limited number of tests were performed in the field because most of the sample was needed for laboratory tests. Moisture contents were determined in conjunction with the strength tests and are expressed as a percentage of the dry sample weight. The measured moisture contents are probably greater than the natural (in situ) water contents because water was used in drilling the hole. Additionally, dilute hydrochloric acid was applied to small areas of the core at regular intervals to test for the presence of carbonates.

Third, most of the logged core was wrapped in cheesecloth, labeled, and coated with polycrystalline wax, then stored in boxes with split styrene inserts to protect the core and to minimize disturbance during transport to U.S. Geological Survey laboratories in Colorado. Samples of coal were not waxed to avoid contamination but, instead, were sealed in plastic sleeves prior to boxing for shipment.

The preliminary geotechnical log we developed is presented in generalized form in figure 5 (in pocket). The $\log$ is presented at a scale of 1 in. $=10$ $\mathrm{ft}$ to facilitate comparison with geophysical logs (described in a later section) that are at the same scale. 
Summary of geotechnical properties

Description of geologic materials

Geologic materials found in the test hole $(1 \mathrm{C}-79)$ are of five principal lithologic types: sandstone, siltstone, claystone, coal, and diamicton (till).

Sandstone beds above the Capps coal bed (above 52-m depth) range in color from light to medium gray and contain mostly fine to very fine, subrounded to subangular grains. The beds are massive to obscurely bedded or laminated, usually have gradational contacts with the material above and below, and range in thickness from $0.1 \mathrm{~m}$ to approximately $1.5 \mathrm{~m}$. The sandstone beds sampled below the Capps coal seam are medium light gray to olive gray, fine to coarse grained, and are very friable. Interbeds of friable small pebble $(<2 \mathrm{~cm})$ conglomerate with subrounded to subangular grains are common.

Siltstone beds are medium light gray to medium gray, massive to obscurely bedded or laminated, and commonly contain thin sandstone or claystone interbeds.

Claystones are medium gray to brownish black, massive to obscurely bedded or laminated, and are in part carbonaceous.

Coals are dusky brown to black, mostly banded (1 ithotypes from vitrain to fusain); they appear massive in part but claystone, siltstone, or carbonaceous shale partings or interbeds are common.

Diamicton extends from near surface to approximately $9 \mathrm{~m}$ in depth and contains poorly sorted materials ranging in size from clay to boulders.

Little or no sign of chemical weathering was observed in the field in the core sample obtained from the hole. The degree and depth of the near-surface 
weathered zone could not be detemined because of extremely poor recovery in the top $9 \mathrm{~m}$ of the core.

All materials found are noncalcareous with the exception of a claystone bed between 83 and $85 \mathrm{~m}$ which had a weak reaction to hydrochloric acid.

Discontinuities

The discontinuities shown in figure 5 include both natural and induced fractures; often it was difficult to distinguish the two. Those discontinuities indicated as joints are believed to be natural fractures. Many of the bedding plane separations are induced. The broken zones in the lower coal (Waterfall bed) are probably induced, but the others appear to be natural. Steeply inclined joints, if present (observed in nearby outcrops), are not adequately represented because of the orientation of the hole.

Strength properties

Rock-mass strength plays an important role in rock engineering. The overall strength is largely controlled by the intact rock strength and by discontinuities such as joints and other preexisting planes or zones of weakness. In general, the greater the strength of the intact rock the more fundamental the effect of discontinuities on the overall strength of the rock mass. According to the strength index tests, unconfined compressive strengths range from 0.20 to $4.20 \mathrm{MPa}$ and average $1.74 \mathrm{MPa}$ (fig. 4). Comparing these values with those compiled by Jennings and Robertson (1969; fig. 4) in relating compressive strength to rock and soil hardness, the test hole material can be categorized as ranging from soft soil to soft rock. Present laboratory testing of the core samples should better define the strength properties of the various materials. 


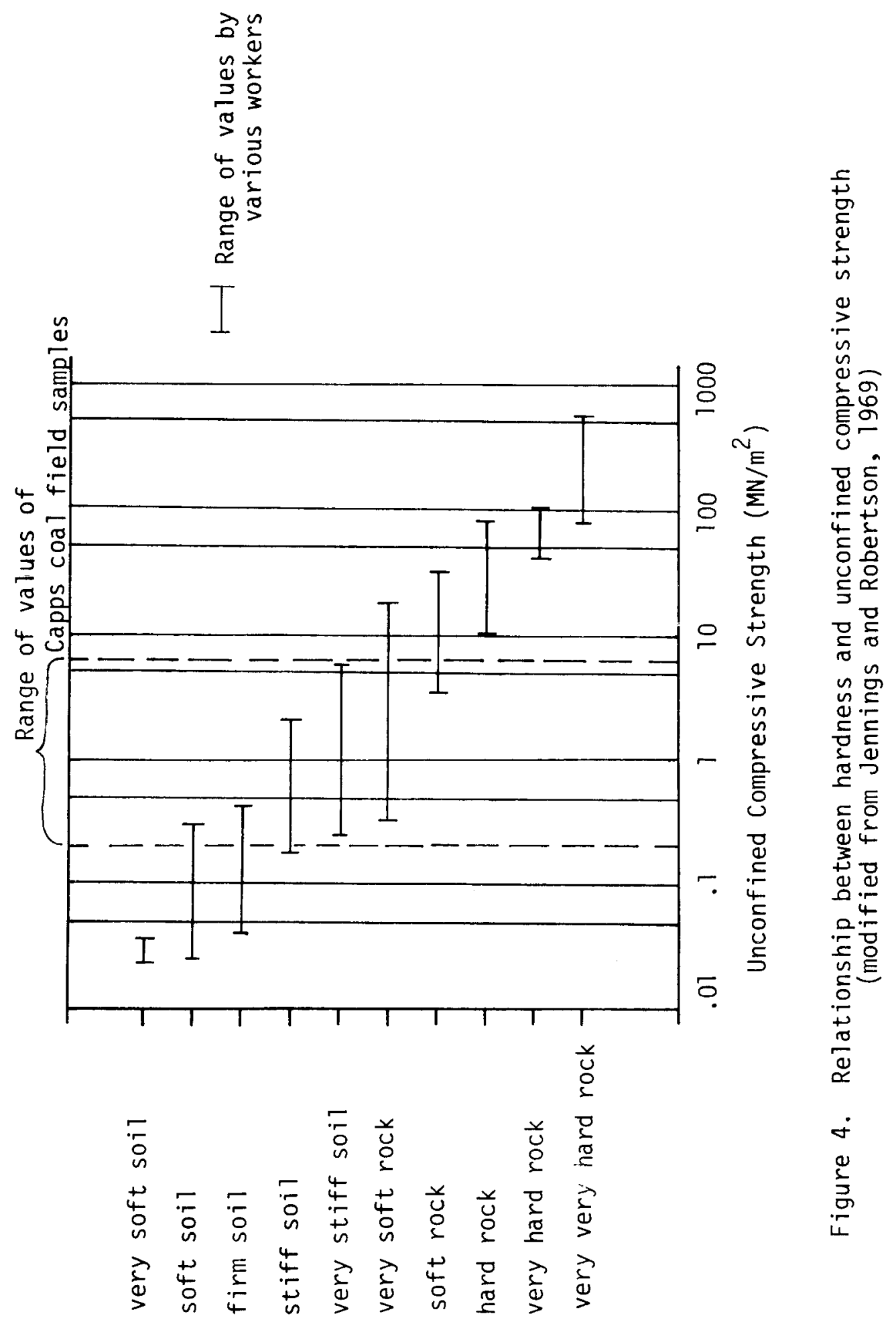




\section{Geophysical logging}

Borehole geophysical logging was performed in the 119-m deep test hole (1C-79) by Larry Dearborn of the U.S. Geological Survey who provided the following details and observations (written commun., 1979) concerning the logs (figs. 7-10). Uncalibrated natural-gamrna, gamma-gamma, and neutron logs, and a calibrated temperature log were completed inside the HQ (7.8-cm I.D.) drill pipe.

Noteworthy enlargements in the drill-hole dianeter are indicated by the caliper $\log (\mathrm{fig} .6)$ at $10 \mathrm{~m}(33 \mathrm{ft})$ and between 21.3 and $36.6 \mathrm{~m}$ (70 and $120 \mathrm{ft})$.

Naturally present radiation detected by the natural-ganma probe (fig. 7) increases to the right on the $\log$ with a span from zero to 100 counts per second (cps). A depth correction of minus 0.6 in $(-2 \mathrm{ft})$ is needed to correct the indicated depth of the log.

The gamma-gamna $\log (f i g .8)$ has a cps span from 0 (left margin) to 5000 (right margin). The water level inside the drill stem is interpreted to be at $22.8 \mathrm{~m}$ and the bottom of the dri1l sten at approximately $109 \mathrm{~m}$. Relative bulk density increases to the left. Cave-ins and washouts lower the density of the area of detection causing a deflection to the right. The strong deflection at $10 \mathrm{~m}(33 \mathrm{ft})$ near the bottom of the surface casing is most likely such a feature.

The neutron log span (fig. 9) is 0-1000 cps above the water in the drill stem $(22.8 \mathrm{~m})$ and $0-400$ cps below that depth. A slight deflection to the right occurred as the probe moved below the surface casing. The log between 67 and $85 \mathrm{~m}(220$ and $280 \mathrm{ft}$ ) and between 88.4 and $112 \mathrm{~m}$ (290 and $368 \mathrm{ft}$ ) suggests a uniform dryness. 
The temperature logs were run inside the drill stem after the hole was allowed to stabilize for 20 hours. The temperature $\log$ (fig. 10) indicates a temperature gradient of approximately $1.6^{\circ} \mathrm{C} / 100 \mathrm{~m}\left(0.9^{\circ} \mathrm{F} / 100 \mathrm{ft}\right)$ for the measured interval of 40.8-118 $\mathrm{m}(134-389 \mathrm{ft})$. In that interval the temperature ranged from $4.1^{\circ} \mathrm{C}\left(39.4^{\circ} \mathrm{F}\right)$ at $40.8 \mathrm{~m}$ (the water-level depth) to $5.1^{\circ} \mathrm{C}\left(41.2^{\circ} \mathrm{F}\right)$ at $118 \mathrm{~m}$. The gradient is $10 \mathrm{w}$ relative to typical gradients $\left(1^{\circ} \mathrm{F} / 100 \mathrm{ft}\right.$ to $\left.1.3^{\circ} \mathrm{F} / 100 \mathrm{ft}\right)$, but is similar to that measured near-surface in an unsuccessful oil well near Anchorage (Keys and MacCary, 1971). In that well, the low-temperature gradients were attributed to significant groundwater circulation.

The following observations and conclusions concerning the temperature log are those of the authors. The anamolous rise in temperature at $118.7 \mathrm{~m}$ $(389 \mathrm{ft})$ (fig. 10) occurs near the top of the Waterfall coal seam. The heat source is possibly an exothermic reaction in the coal caused by frictional forces generated in the drilling process. High drilling pressure was applied at that depth $(119 \mathrm{~m})$ in an effort to core the coal, with what was later detemined to be a badly worn bit. Use of this resulted in an irreparably bent core sampler, a very slow drilling rate, and badly disturbed core sample. Some of the retrieved sample was badly broken and smelled like cresote and hydrogen sulfide. The temperature probe was raised and lowered several times to check the validity of the local heat source and then left stationary at the 118.7-m (389-ft) level (the bottom of the hole) for about 2 hours. A maximum temperature of $10.7^{\circ} \mathrm{C}\left(51.2^{\circ} \mathrm{F}\right)$ was recorded at the end of the 2-hour period. 
Hydrology

The following hydrologic conditions are based on information obtained from the 76-m deep test hole $30 \mathrm{~m}$ south of hole $1 \mathrm{C}-79$ (G. L. Nelson, U.S. Geological Survey, written commun., 1979): "The materials were unsaturated to the total depth except for a few thin perched water table zones. Only the perched water table zone at $9.1 \mathrm{~m}$ yielded any measurable water (about 2 L/min). A little seepage was detected between 40.8 and $41.4 \mathrm{~m}$. The zone between 60.9 and $76.2 \mathrm{~m}$ is quite permeable $(380 \mathrm{~L} / \mathrm{min}(100 \mathrm{gal} / \mathrm{min})$ were injected into the well after drilling)."

The geotechnical $\log (f i g .5)$ shows that the perched water table zone at $9.1 \mathrm{~m}$ corresponds to the contact between the surficial till and the underlying claystone, indicating that the claystone is an aquiclude inhibiting the downward migration of water. The seepage detected between 40.8 and $41.4 \mathrm{~m}$ corresponds to the upper part of the Capps coal searl and the base of the carbonaceous claystone (shale?) above. The permeable zone between 60.9 and $76.2 \mathrm{~m}$ corresponds to what is mostly a nonrecovery zone thought to be composed of friable sandstone. The only direct indication of hydrologic conditions between 76.2 and $121 \mathrm{~m}$ comes from test hole no. 1C-79 where circulation of drilling fluid was never attained, indicating a downward continuation of the unsaturated permeable material. 


\section{References}

Adkison, W. L., Kelley, J. S., and Newman, K. R., 1975, Lithology and palynology of Tertiary rocks exposed near Capps Glacier and along Chuitna River, Tyonek quadrangle, southern Alaska: U.S. Geological Survey OpenFile Report 75-21, $58 \mathrm{p}$.

Barnes, F. F., 1966, Geology and coal resources of the Beluga-Yentna region, Alaska: U.S. Geological Survey Bulletin 1202-C, 54 p.

Broch, E., and Franklin, J. A., 1972, The point-load strength test: International Journal of Rock Mechanics and Mining Sciences, v. 9, no. 6, p. $669-697$.

Franklin, J. A., Broch, E., and Walton, G., 1972, Logging the mechanical character of the rock: Institution of Mining and Metallurgy Transactions, p. A43-A51.

Goddard, E. N., chm., and others, 1943, Rock-color chart: National Research Council; reprinted by Geological Society of Alnerica, 1951, 1963, 1970, $6 \mathrm{p}$.

Jennings, J. E., and Robertson, A., 1969, The stability of slopes cut into natural rock: International Conference Soil Mechanics and Foundation Engineering, 7th, Mexico, Proceedings, v. 2, p. 585-590. Keys, W. S., and MacCary, L. M., 1971, Application of borehole geophysics to water-resources investigations, Chapter E1: U.S. Geological Survey Techniques of Water-Resources Investigations TWI 2-E1, 126 p. Magoon, L. B., Adkison, W. L., and Egbert, R. M., 1976, Map showing geology, wildcat wells, Tertiary plant fossil localities, K-Ar age dates, and petroleum operations, Cook Inlet area, Alaska: U.S. Geological Survey Miscellaneous Investigations Map I-1019, 2 sheets, scale 1:250,000. 
Patsch, B. J. G., 1975, Exploration and development of the Beluga coal field, in Rao, P. D., and Wolff, E. N., eds., Focus on Alaska's Coal '75, Conference, Fairbanks [ Alaska], October 15-17, 1975, Proceedings:

Fairbanks, University of Alaska, School of Mineral Industry, MIRL Report 37; and Federal Energy Administration, Anchorage, p. 72-83. Rankilor, P. R., 1974, A suggested field system of logging rock cores for engineering purposes: Association of Engineering Geologists Bulletin, v. 11 , no. 3 , p. 247-258.

Soiltest, Inc., 1978, Pocket penetrometer operating details--Soiltest model CL-700: Soiltest, Inc., 2205 Lee Street, Evanston, I1linois, 60202, Bul let in 151-64, [pamphl et]. Wolfe, J. A., and Tanai, T., 1980, The Miocene Seldovia Point Flora from the Kenai Group, Alaska: U.S. Geological Survey Professional Paper 1105, $52 \mathrm{p}$. 